\title{
Recent advances in deep brain stimulation in psychiatric
}

\section{disorders [version 1; peer review: 2 approved]}

\author{
Anne-Hélène Clair (iD1, William Haynes ${ }^{1,2}$, Luc Mallet L $^{1,3}$ \\ ${ }^{1}$ Sorbonne University, UPMC Paris 06 University, INSERM, CNRS, Institut du Cerveau et de la Moelle épinière, Paris, France \\ ${ }^{2}$ Neurosurgery department, University Hospital of Montpellier, Montpellier, France \\ ${ }^{3}$ Psychiatry and Addictology Department - Neurosurgery Department, Personalized Neurology \& Psychiatry University Department, \\ University Hospitals Henri Mondor - Albert Chenevier, Créteil, France
}

V1 First published: 05 Jun 2018, 7(F1000 Faculty Rev):699

https://doi.org/10.12688/f1000research.14187.1

Latest published: 05 Jun 2018, 7(F1000 Faculty Rev):699

https://doi.org/10.12688/f1000research.14187.1

\section{Open Peer Review}

Approval Status

1

2

version 1

05 Jun 2018

Faculty Reviews are review articles written by the prestigious Members of Faculty Opinions. The articles are commissioned and peer reviewed before publication to ensure that the final, published version is comprehensive and accessible. The reviewers who approved the final version are listed with their names and affiliations.

1. Tipu Z. Aziz, University of Oxford, Oxford, UK John Radcliffe Hospital, Oxford, UK

2. Jens Volkmann, University Hospital of Würzburg, Würzburg, Germany Any comments on the article can be found at the end of the article.
Keywords

deep brain stimulation, obsessive-compulsive disorder, major depression, gilles de la Tourette syndrome, psychosurgery 
Corresponding author: Anne-Hélène Clair (ah.clair@gmail.com)

Author roles: Clair AH: Conceptualization, Resources, Writing - Original Draft Preparation, Writing - Review \& Editing; Haynes W: Writing - Review \& Editing; Mallet L: Conceptualization, Writing - Review \& Editing

Competing interests: No competing interests were disclosed.

Grant information: The author(s) declared that no grants were involved in supporting this work.

Copyright: $\odot 2018$ Clair AH et al. This is an open access article distributed under the terms of the Creative Commons Attribution License, which permits unrestricted use, distribution, and reproduction in any medium, provided the original work is properly cited.

How to cite this article: $\mathrm{Clair} A H$, Haynes $\mathrm{W}$ and Mallet $\mathrm{L}$. Recent advances in deep brain stimulation in psychiatric disorders [version 1; peer review: 2 approved] F1000Research 2018, 7(F1000 Faculty Rev):699 https://doi.org/10.12688/f1000research.14187.1

First published: 05 Jun 2018, 7(F1000 Faculty Rev):699 https://doi.org/10.12688/f1000research.14187.1 


\section{Introduction}

Deep brain stimulation (DBS) is a neurosurgical technique based on the stereotactic implantation of quadripolar electrodes delivering high-frequency current in a specific subcortical or deep cortical structure. It is usually indicated to decrease symptoms in neurological disorders, such as the hypodopaminergic symptom spectrum associated with Parkinson's disease (PD). The reversibility of DBS, supporting its ethically "acceptable" status, combined with the improvement of psychiatric symptoms after lesional surgeries has certainly led to the transition towards its application in psychiatric disorders ${ }^{1}$. Patients with severe debilitating disease, resistant to medical and psychotherapeutic optimal treatment, were enrolled in studies modulating corticostriato-thalamo-cortical circuits with DBS.

DBS was first used to improve obsessive-compulsive disorder $(\mathrm{OCD})^{2}$ and Gilles de la Tourette syndrome (TS $)^{3}$ symptoms in 1999. In both disorders, patients feel compelled to perform repetitive motor and vocal tics (in TS) or repetitive behaviour associated with intrusive ideas (compulsions and obsessions) (in OCD). Based on the efficacy of previous lesional surgeries ${ }^{1}$, the first targets were the anterior limb of internal capsule (ALIC) ${ }^{2}$ in OCD and the centromedian-parafascicular complex (CM-Pf) in $\mathrm{TS}^{3} ; 3$ years later, an important decrease of comorbid OCD symptoms was reported in two parkinsonian patients stimulated in the subthalamic nucleus $(\mathrm{STN})^{4}$. The same year, given the effects of globus pallidus internus (GPi) DBS on hyperkinesia in $\mathrm{PD}$, a patient with TS was stimulated in the postero-ventral GPi and showed postoperative clinical improvement ${ }^{5}$. Then, based on pathophysiological evidence involving the subgenual cortex (BA 25, also termed $\mathrm{Cg} 25$ ) in major depressive disorder (MDD), the modulation of this structure with DBS was tested and led to an improvement of MDD symptoms ${ }^{6}$. Here, we will present the recent developments of DBS in psychiatry, including the clinical outcomes for OCD, TS, and MDD patients and other emerging psychiatric applications.

\section{Obsessive-compulsive disorder}

Randomised controlled studies have confirmed the initial reports by B. Nuttin ${ }^{2}$ and L. Mallet ${ }^{4}$ and highlighted two main targets for OCD: the striatal region (including the ALIC, the nucleus accumbens, the ventral caudate nucleus, and the ventral capsule/ventral striatum) $)^{7-9}$ and the $\mathrm{STN}^{10}$. Two recent meta-analysesfound that DBS leads to a global decrease of about $45 \%$ of OCD symptom severity with $60 \%$ of patients considered responders ${ }^{11,12}$.

Recent studies are now focusing on the long-term effects of DBS, which represents a decisive step to consider a broader application of DBS for OCD. In agreement with the report from Greenberg et al. 3 years after DBS in the striatal region, a stability of the initial decrease of OCD symptoms has been reported until 9 years after $\mathrm{DBS}^{13,14}$. Case reports that also suggest a stability of symptom decrease 6 months ${ }^{15}$ and 10 years after STN stimulation ${ }^{16,17}$ have been published.

In addition, one may wonder whether the evaluation of DBS efficacy is limited to the decrease of OCD symptoms (as measured by the Yale-Brown Obsessive Compulsive Scale, or Y-BOCS). The recent focus on quality of life is related to a chronological (that is, after proving symptoms reduction), historical (that is, regarding the past misconducts in psychosurgery), and transnosographic (see Agid et $a l .{ }^{18}$ ) legacy. Indeed, the team of D. Denys has chosen to follow its initial cohort $^{9}$ by evaluating as a primary outcome the quality of life and subjective lived experience of the patients stimulated in the striatal region ${ }^{13,19,20}$. After 3 to 5 years of DBS, patients reported a significant improvement in quality of life ${ }^{13}$. Curiously, it improved in responders and non-responders to DBS as defined by Y-BOCS fluctuations, thereby questioning the psychometric limits and the relevance of this primary outcome measure for severe populations. In addition to the previously known effects of striatal DBS (for example, mood and anxiety), patients of this cohort reported that they became "more easy and loose", "more self-confident", and "expressive" but also experienced "difficulties in their relationship with partner" after $\mathrm{DBS}^{19}$. Changes regarding the perception of themselves, their families, and other problems with social adjustments have been noticed in parkinsonian patients after clinical improvement by STN DBS ${ }^{21}$. Thus, the psychological and social changes experienced by patients with OCD could be unspecific and highlight the lack of control groups in the studies on DBS for $\mathrm{OCD}^{13,19}$. Currently, a European multicentre study is comparing the quality of life of severe OCD patients stimulated in the STN versus optimised conventional treatment ${ }^{17}$.

In the study by De Haan et al., we also noticed that patients reported an effect of DBS on the ability to engage in cognitive behavioural therapy $(\mathrm{CBT})^{19}$. Notwithstanding that almost all of the OCD patients included in DBS studies had initially failed to complete CBT, the cohort of D. Denys et al. ${ }^{9}$ experienced an additional decrease of OCD symptoms after post-operative $\mathrm{CBT}^{22}$. This interesting result places CBT as a potential strategy to enhance an often-partial response to striatal DBS in OCD and raises the interest in assessing this effect after STN stimulation.

Finally, the search for an optimal target in OCD is ongoing. Although a recent meta-analysis failed to find a significant difference between the efficacy of DBS in the striatal region and $\mathrm{STN}^{12}$, a multicentre randomised trial is currently comparing the efficacy and safety of ventral capsule/ventral striatum versus STN DBS for OCD (ClinicalTrials.gov identifier NCT01329133). Otherwise, a case study reported a decrease in OCD symptoms after DBS of the medial forebrain bundle (MFB) $)^{23}$, a promising target in $\mathrm{MDD}^{24}$.

\section{Gilles de la Tourette syndrome}

In the same way as $\mathrm{OCD}$, the promising results reported in the two initial case studies ${ }^{3,5}$ were replicated, identifying two main targets for TS: the thalamus (including CM-Pf, dorsomedial nucleus, ventro-anterior and ventro-lateral) and the GPi (including the motor part [that is, postero-ventral] and associative-limbic part [that is, antero-medial]). For both targets, a recent meta-analysis also confirmed the efficacy of DBS with a median improvement of $52 \%$ in tic severity ${ }^{25}$. However, this encouraging result is based mostly on open-label studies. It included only three randomised controlled studies, which had contradictory results, 
obtained from small samples, and most of them targeting the thalamus ${ }^{26-28}$. Thus, the efficacy of DBS for TS seems to be lacking evidence, especially in the GPi, a promising target with fewer side effects than the thalamus.

With the aim of providing evidence of the efficacy of GPi DBS on TS, two double-blind cross-over studies were recently conducted in larger samples ${ }^{29,30}$. Unfortunately, although the team of Kefalopoulou $^{29}$ found a significant decrease of (only) $15 \%$ in tic severity during the double-blind phase, no significant difference was measured by Welter et al..$^{30}$. However, for both, the improvement went up to $40 \%$ during the (open-label) follow-up period, and there were many inter-individual differences. This clearly highlights the difficulties in finding results in double-blind studies that are as encouraging as those in open-label ones. The placebo effect but also methodological issues (for example, duration of the blind period and limitation of the stimulation settings to preserve masking) and the chosen target (motor or associative-limbic part of the GPi) could explain this difference ${ }^{29,30}$. These limitations would probably be examined by the innovative database ${ }^{31}$ recently created to consider new guidelines for trials using DBS in TS. The aim of this database was also to share and gather clinical experiences with DBS in $\mathrm{TS}^{31}$, which offer a faster accumulation of evidence for DBS efficacy.

Recent studies are now interested in the long-term effects of DBS, as in OCD. Long-term side effects already reported after thalamic stimulation ${ }^{32}$ have even led some authors to propose a different target to their patients with $\mathrm{TS}^{33}$. Conversely, the longterm follow-up of TS patients stimulated in the GPi gave encouraging results ${ }^{34,35}$, including an improvement in quality of life $^{36}$. Unfortunately, as already reported in patients with $\mathrm{OCD}^{19,20}$ and $\mathrm{PD}^{21}$, patients have difficulties in coping with changes after $\mathrm{DBS}^{36}$. Consistently, the author stressed the importance of a multidisciplinary team and the need to approach patients about "how life will continue with or without tics" ${ }^{36}$. This relevant consideration has already been successfully tested in PD patients with a perioperative psychoeducation program, leading to better social adaptation and a decrease of anxiety and depression ${ }^{37}$. Given the numerous psychiatric diseases often comorbid to TS, such a support program could be an interesting strategy to increase an often-partial response to DBS in TS.

\section{Major depressive disorder}

Although the literature on DBS for patients with MDD is relatively recent, numerous open-label studies have highlighted a decrease of depressive symptoms after DBS. Indeed, the results of the first trial stimulating $\mathrm{Cg} 25^{6}$ were confirmed by subsequent studies $^{38-40}$. As is the case for OCD, DBS of the ventral striatal region leads to improvement of depressive symptoms in open-label studies $^{41-43}$.

Recently, the efficacy of DBS in MDD was tested in two large double-blind randomised sponsored studies. Inclusions of patients in these studies began shortly after the initial publication by Mayberg et $a l .{ }^{6}$, probably motivated by the influence of highlevel studies on a wider application of DBS and the frequency of MDD. Targeting the striatal region, a first study planned to include more than $200 \mathrm{MDD}$ patients for $\mathrm{DBS}^{44}$. It was prematurely interrupted after including (only) 29 patients, as no significant difference was measured between the stimulated and non-stimulatedgroups. The same was observed for the largest DBS study in psychiatry, which failed to find significant differences after the stimulation of $\mathrm{Cg} 25$ among the 90 MDD patients included ${ }^{45}$. These disappointing results are counterbalanced by the recent demonstration of significant improvement in MDD symptoms after ALIC DBS (with $40 \%$ of responders) in a third trial ${ }^{46}$. This last study is still the only randomised controlled trial to show a significant effect of DBS on depression.

Taken together, these recent results highlighted the safety of DBS in MDD. However, one cannot conclude whether DBS has an effect on depression. Trying to find the reasons for this "failure" is a current debate within the DBS community. Some have pointed to the methodology of the randomised trials, specifically the way (for example, the delay and the algorithm used) to find the optimal stimulation parameters, and even the design of the study (for example, a cross-over versus parallel design and the duration between inclusion and blind period). Furthermore, the clinical characteristics of the patients with MDD are criticised, especially the duration of symptoms in some patients (up to 12 years) that could lead to a potential delayed effect of $\mathrm{DBS}^{45}$ or be a measured manifestation of a special clinical phenotype of non-responder patients. The fact that the results have not been very encouraging until now reasonably raises the question of whether or not to continue trials with this invasive procedure in psychiatric patients.

However, these negative results could be explained by a target issue. Indeed, a dramatic improvement of depressive symptoms was measured after DBS of the supero-lateral medial forebrain bundle (slMFB) in open-label studies ${ }^{24,47}$. Now, one could wait for the results from a randomised study targeting this structure in $\mathrm{MDD}^{48}$. They would be of particular interest to confirm, as $75 \%$ of patients are still responders 1 year after the start of DBS and have no serious side effects ${ }^{48}$.

\section{Other psychiatric disorders}

In recent years, several successful cases of DBS application to different neuropsychiatric disorders have been reported. As mentioned by the authors, those cases are in fact indicative of forthcoming open-label studies. If all of them succeed, we will know whether DBS of the slMFB decreases depressive symptoms in bipolar patients ${ }^{49}$, whether the stimulation of baso-lateral amygdala improves resistant post-traumatic stress disorder ${ }^{50}$, and whether DBS of the striatal region is effective in heroin ${ }^{51}$ or cocaine ${ }^{52}$ addiction or even in schizophrenia ${ }^{53}$.

In patients with resistant anorexia nervosa (AN), encouraging first results were obtained on their body mass index (BMI) after the stimulation of $\mathrm{Cg} 25^{54}$. Even if the first open-label study, including six $\mathrm{AN}$ patients stimulated in $\mathrm{Cg} 25$, led to disappointing results concerning the evolution of $\mathrm{BMI}^{55}$, a significant increase of BMI was then measured in a larger group (16 patients with AN) stimulated in the same target ${ }^{54}$. Additionally to an increase in 
BMI, patients have experienced an improvement in mood and anxiety. As the same team have already used this target to decrease depressive symptoms in $\mathrm{MDD}^{6,38}$, one cannot exclude a positive bias of mood on the primary outcome measure (BMI). Other open-label trials are ongoing to replicate these results and to test the efficacy of other targets (especially the striatal region) in AN (ClinicalTrials.gov identifiers NCT03168893 and NCT01924598).

\section{Conclusions}

Long-term effects of DBS are encouraging about both the absence of relapse and the improvement in quality of life in severe and resistant TS and OCD. On the other hand, recent years have been marked by disappointing results of randomised studies in DBS for TS and MDD.

This raises the question of DBS' efficacy for psychiatric disorders, framed by a growing concern for ethics ${ }^{56,57}$. Key principles of medical ethics are discussed, such as the ability to make an autonomous decision (also suggesting giving informed consent) or authorize a research procedure ${ }^{58}$ or changes in personality following $\mathrm{DBS}^{20}$. A consensus document on ethical and scientific conduct for psychiatric surgery was recently published ${ }^{56}$. This document also mentioned that to make a conclusion regarding DBS' efficiency (for a specific psychiatric population stimulated in a specific target), at least two studies managed by two different teams are necessary ${ }^{56}$. Today, despite numerous randomised trials, no target in any psychiatric disease can meet these criteria.

This could be partially explained by heterogeneous clinical manifestations of psychiatric patients within a common diagnosis. Indeed, the DBS of a defined target may modulate the symptoms linked to a specific dysfunctional and partially overlapping neuronal circuit involved in psychiatric manifestations ${ }^{59}$.

Shared databases, as recently initiated for DBS in TS, are an encouraging way to promote scientific reflexion and hopefully improve clinical efficacy of DBS in TS and maybe in other psychiatric disorders. This could also contribute to the identification of optimal targets for specific subgroups of patients, paving the way to precision medicine in psychiatry for severe and refractory mental disorders.

\section{Competing interests}

The authors declare that they have no competing interests.

\section{Grant information}

The author(s) declared that no grants were involved in supporting this work.
1. Hariz MI, Blomstedt P, Zrinzo L: Deep brain stimulation between 1947 and 1987 the untold story Neurosurg Focus. 2010; 29(2): E1. PubMed Abstract | Publisher Full Text

2. Nuttin $\mathrm{B}$, Cosyns $\mathrm{P}$, Demeulemeester $\mathrm{H}$, et al.: Electrical stimulation in anterior limbs of internal capsules in patients with obsessive-compulsive disorder. Lancet. 1999; 354(9189): 1526. PubMed Abstract | Publisher Full Text

3. Vandewalle V, van der Linden C, Groenewegen $\mathrm{HJ}$, et al:: Stereotactic treatment of Gilles de la Tourette syndrome by high frequency stimulation of thalamus. Lancet. 1999; 353(9154): 724.

PubMed Abstract | Publisher Full Text

4. Mallet L, Mesnage V, Houeto JL, et al.: Compulsions, Parkinson's disease, and stimulation. Lancet. 2002; 360(9342): 1302-4. PubMed Abstract | Publisher Full Text

5. Van der Linden C, Colle H, Vandewalle V, et al:: Successful treatment of tics with bilateral internal pallidum (GPi) stimulation in a 27 -year-old male patient with Gilles de la Tourette's syndrome. Mov Disord. 2002; 17(Suppl 5): S341-S341.

6. F Mayberg HS, Lozano AM, Voon V, et al:: Deep brain stimulation for treatment-resistant depression. Neuron. 2005; 45(5): 651-60. PubMed Abstract | Publisher Full Text | F1000 Recommendation

7. Greenberg BD, Malone DA, Friehs GM, et al.: Three-year outcomes in deep brain stimulation for highly resistant obsessive-compulsive disorder. Neuropsychopharmacology. 2006; 31(11): 2384-93. PubMed Abstract | Publisher Full Text

8. F Goodman WK, Foote KD, Greenberg BD, et al:: Deep brain stimulation for intractable obsessive compulsive disorder: pilot study using a blinded, staggered-onset design. Biol Psychiatry. 2010; 67(6): 535-42. PubMed Abstract | Publisher Full Text | Free Full Text | F1000 Recommendation

9. F Denys D, Mantione M, Figee M, et al.: Deep brain stimulation of the nucleus accumbens for treatment-refractory obsessive-compulsive disorder. Arch Gen Psychiatry. 2010; 67(10): 1061-8. PubMed Abstract | Publisher Full Text | F1000 Recommendation

10. F Mallet L, Polosan M, Jaafari N, et al.: Subthalamic nucleus stimulation in severe obsessive-compulsive disorder. N Engl J Med. 2008; 359(20): 2121-34. PublMed Abstract | Publisher Full Text | F1000 Recommendation

11. Kisely S, Hall K, Siskind D, et al.: Deep brain stimulation for obsessivecompulsive disorder: a systematic review and meta-analysis. Psychol Med. 2014; 44(16): 3533-42.

PubMed Abstract | Publisher Full Text

12. Alonso P, Cuadras D, Gabriëls L, et al.: Deep Brain Stimulation for ObsessiveCompulsive Disorder: A Meta-Analysis of Treatment Outcome and Predictors of Response. PLoS One. 2015; 10(7): e0133591. PubMed Abstract | Publisher Full Text | Free Full Text

13. Ooms $\mathrm{P}$, Mantione $\mathrm{M}$, Figee $\mathrm{M}$, et al.: Deep brain stimulation for obsessivecompulsive disorders: long-term analysis of quality of life. $J$ Neurol Neurosurg Psychiatry. 2014; 85(2): 153-8.

PubMed Abstract | Publisher Full Text

14. F Fayad SM, Guzick AG, Reid AM, et al:: Six-Nine Year Follow-Up of Deep Brain Stimulation for Obsessive-Compulsive Disorder. PLoS One. 2016; 11(12): e0167875.

PubMed Abstract | Publisher Full Text | Free Full Text | F1000 Recommendation

15. Chabardès $S$, Polosan $M, K$ rack $P$, et al.: Deep brain stimulation for obsessivecompulsive disorder: subthalamic nucleus target. World Neurosurg. 2013; 80(3-4): S31.e1-8.

PubMed Abstract | Publisher Full Text

16. $\mathrm{F}$ Polosan $\mathrm{M}$, Chabardes $\mathrm{S}$, Bougerol $\mathrm{T}$, et al.: Long-term improvement in obsessions and compulsions with subthalamic stimulation. Neurology. 2016; 87(17): 1843-4.

PubMed Abstract | Publisher Full Text | F1000 Recommendation

17. Krack $\mathrm{P}$, Polosan $\mathrm{M}$, Chabardès $\mathrm{S}$, et al.: Author response: Long-term improvement in obsessions and compulsions with subthalamic stimulation. Neurology. 2017; 88(17): 1684 PubMed Abstract | Publisher Full Text

18. Agid $\mathrm{Y}$, Schüpbach $\mathrm{M}$, Gargiulo $\mathrm{M}$, et al.: Neurosurgery in Parkinson's disease: the doctor is happy, the patient less so? J Neural Transm Suppl. 2006; (70) 409-14.

PubMed Abstract | Publisher Full Text 
19. de Haan S, Rietveld E, Stokhof M, et al: Effects of Deep Brain Stimulation on the Lived Experience of Obsessive-Compulsive Disorder Patients: In-Depth Interviews with 18 Patients. PLoS One. 2015; 10(8): e0135524. PubMed Abstract | Publisher Full Text | Free Full Text

20. F de Haan S, Rietveld E, Stokhof $\mathrm{M}$, et al.: Becoming more oneself? Changes in personality following DBS treatment for psychiatric disorders: Experiences of OCD patients and general considerations. PLOS One. 2017; 12(4): e0175748. PubMed Abstract | Publisher Full Text | Free Full Text | F1000 Recommendation

21. Schüpbach M, Gargiulo M, Welter ML, et al.: Neurosurgery in Parkinson disease: a distressed mind in a repaired body? Neurology. 2006; 66(12): 1811-6. PubMed Abstract | Publisher Full Text

22. Mantione M, Nieman DH, Figee M, et al.: Cognitive-behavioural therapy augments the effects of deep brain stimulation in obsessive-compulsive disorder. Psychol Med. 2014; 44(16): 3515-22. PubMed Abstract | Publisher Full Text

23. F Coenen VA, Schlaepfer TE, Goll P, et al.: The medial forebrain bundle as a target for deep brain stimulation for obsessive-compulsive disorder. CNS Spectr. 2017; 22(3): 282-9.

PubMed Abstract | Publisher Full Text | F1000 Recommendation

24. F Schlaepfer TE, Bewernick BH, Kayser S, et al:: Rapid effects of deep brain stimulation for treatment-resistant major depression. Biol Psychiatry. 2013; 73(12): 1204-12

PubMed Abstract | Publisher Full Text | F1000 Recommendation

25. F Baldermann JC, Schüller T, Huys D, et al:: Deep Brain Stimulation for Tourette-Syndrome: A Systematic Review and Meta-Analysis. Brain Stimul. 2016; 9(2): 296-304.

PubMed Abstract | Publisher Full Text | F1000 Recommendation

26. Maciunas RJ, Maddux BN, Riley DE, et al:: Prospective randomized doubleblind trial of bilateral thalamic deep brain stimulation in adults with Tourette syndrome. J Neurosurg. 2007; 107(5): 1004-14.

PubMed Abstract | Publisher Full Text

27. $\mathrm{F}$ Welter ML, Mallet $\mathrm{L}$, Houeto JL, et al:: Internal pallidal and thalamic stimulation in patients with Tourette syndrome. Arch Neurol. 2008; 65(7): 952-7. PubMed Abstract | Publisher Full Text | F1000 Recommendation

28. Ackermans L, Duits A, van der Linden C, et al:: Double-blind clinical trial of thalamic stimulation in patients with Tourette syndrome. Brain. 2011; 134(Pt 3): 832-44.

PubMed Abstract | Publisher Full Text

29. $\mathrm{F}$ Kefalopoulou Z, Zrinzo L, Jahanshahi M, et al.: Bilateral globus pallidus stimulation for severe Tourette's syndrome: a double-blind, randomised crossover trial. Lancet Neurol. 2015; 14(6): 595-605. PubMed Abstract | Publisher Full Text | F1000 Recommendation

30. F Welter ML, Houeto JL, Thobois S, et al:: Anterior pallidal deep brain stimulation for Tourette's syndrome: a randomised, double-blind, controlled trial. Lancet Neurol. 2017; 16(8): 610-9.

PubMed Abstract | Publisher Full Text | F1000 Recommendation

31. Deeb W, Rossi PJ, Porta M, et al:: The International Deep Brain Stimulation Registry and Database for Gilles de la Tourette Syndrome: How Does It Work? Front Neurosci. 2016; 10: 170

PubMed Abstract | Publisher Full Text

32. Porta M, Servello D, Zanaboni C, et al.: Deep brain stimulation for treatment of refractory Tourette syndrome: Iong-term follow-up. Acta Neurochir (Wien). 2012; 154(11): 2029-41.

PubMed Abstract | Publisher Full Text

33. F Smeets AYJM, Duits AA, Leentjens AFG, et al:: Thalamic Deep Brain Stimulation for Refractory Tourette Syndrome: Clinical Evidence for Increasing Disbalance of Therapeutic Effects and Side Effects at Long-Term Follow-Up. Neuromodulation. 2018; 21(2): 197-202.

PubMed Abstract | Publisher Full Text | F1000 Recommendation

34. Sachdev PS, Mohan A, Cannon E, et al:: Deep brain stimulation of the anteromedial globus pallidus interna for Tourette syndrome. PLoS One. 2014; 9(8): e104926.

PubMed Abstract | Publisher Full Text | Free Full Text

35. F Smeets AYJM, Duits AA, Plantinga BR, et al.: Deep Brain Stimulation of the internal globus pallidus in refractory Tourette Syndrome. Clin Neurol Neurosurg. 2016; 142: 54-9.

PubMed Abstract | Publisher Full Text | F1000 Recommendation

36. Dehning S, Leitner B, Schennach R, et al.: Functional outcome and quality of life in Tourette's syndrome after deep brain stimulation of the posteroventrolateral globus pallidus internus: long-term follow-up. World J Biol Psychiatry. 2014; 15(1): 66-75.

PubMed Abstract | Publisher Full Text

37. Flores Alves Dos Santos J, Tezenas du Montcel S, Gargiulo M, et al:: Tackling psychosocial maladjustment in Parkinson's disease patients following subthalamic deep-brain stimulation: A randomised clinical trial. PLOS One. 2017; 12(14): e0174512.

PubMed Abstract | Publisher Full Text | Free Full Text

38. F Lozano AM, Mayberg HS, Giacobbe P, et al.: Subcallosal cingulate gyrus deep brain stimulation for treatment-resistant depression. Biol Psychiatry. 2008; 64(6): 461-7.

PubMed Abstract | Publisher Full Text | F1000 Recommendation

39. F Kennedy SH, Giacobbe P, Rizvi SJ, et al.: Deep brain stimulation for treatment-resistant depression: follow-up after 3 to 6 years. Am J Psychiatry. 2011; 168(5): 502-10.

PubMed Abstract | Publisher Full Text | F1000 Recommendation

40. F Holtzheimer PE, Kelley ME, Gross RE, et al.: Subcallosal cingulate deep brain stimulation for treatment-resistant unipolar and bipolar depression. Arch Gen Psychiatry. 2012; 69(2): 150-8.

PubMed Abstract | Publisher Full Text | Free Full Text | F1000 Recommendation

41. F Malone DA Jr, Dougherty DD, Rezai AR, et al:: Deep brain stimulation of the ventral capsule/ventral striatum for treatment-resistant depression. Biol Psychiatry. 2009; 65(4): 267-75.

PubMed Abstract | Publisher Full Text | Free Full Text | F1000 Recommendation

42. Bewernick BH, Kayser S, Sturm V, et al.: Long-term effects of nucleus accumbens deep brain stimulation in treatment-resistant depression: evidence for sustained efficacy. Neuropsychopharmacology. 2012; 37(9): 1975-85.

PubMed Abstract | Publisher Full Text | Free Full Text

43. F Schlaepfer TE, Cohen MX, Frick C, et al.: Deep brain stimulation to reward circuitry alleviates anhedonia in refractory major depression. Neuropsychopharmacology. 2008; 33(2): 368-77.

PubMed Abstract | Publisher Full Text | F1000 Recommendation

44. Dougherty DD, Rezai AR, Carpenter LL, et al:: A Randomized Sham-Controlled Trial of Deep Brain Stimulation of the Ventral Capsule/Ventral Striatum for Chronic Treatment-Resistant Depression. Biol Psychiatry. 2015; 78(4): 240-8. PubMed Abstract | Publisher Full Text

45. $\mathrm{F}$ Holtzheimer PE, Husain MM, Lisanby SH, et al:: Subcallosal cingulate deep brain stimulation for treatment-resistant depression: a multisite, randomised, sham-controlled trial. Lancet Psychiatry. 2017; 4(11): 839-49.

PubMed Abstract | Publisher Full Text | F1000 Recommendation

46. F Bergfeld IO, Mantione M, Hoogendoorn ML, et al.: Deep Brain Stimulation of the Ventral Anterior Limb of the Internal Capsule for Treatment-Resistant Depression: A Randomized Clinical Trial. JAMA Psychiatry. 2016; 73(5): 456-64. PubMed Abstract | Publisher Full Text | F1000 Recommendation

47. F Fenoy AJ, Schulz P, Selvaraj S, et al:: Deep brain stimulation of the medial forebrain bundle: Distinctive responses in resistant depression. $J$ Affect Disord. 2016; 203: 143-51.

PubMed Abstract | Publisher Full Text | F1000 Recommendation

48. F Bewernick BH, Kayser S, Gippert SM, et al.: Deep brain stimulation to the medial forebrain bundle for depression- long-term outcomes and a novel data analysis strategy. Brain Stimul. 2017; 10(3): 664-71.

PubMed Abstract | Publisher Full Text | F1000 Recommendation

49. F Gippert SM, Switala C, Bewernick BH, et al.: Deep brain stimulation for bipolar disorder-review and outlook. CNS Spectr. 2017; 22(3): 254-7. PubMed Abstract | Publisher Full Text | F1000 Recommendation

50. F Langevin J, Koek RJ, Schwartz HN, et al:: Deep Brain Stimulation of the Basolateral Amygdala for Treatment-Refractory Posttraumatic Stress Disorder. Biol Psychiatry. 2016; 79(10): e82-e84.

PubMed Abstract | Publisher Full Text | F1000 Recommendation

51. Kuhn J, Bührle CP, Lenartz D, et al.: Deep brain stimulation in addiction due to psychoactive substance use. Handb Clin Neurol. 2013; 116: 259-69. PubMed Abstract | Publisher Full Text

52. F Gonçalves-Ferreira A, do Couto FS, Rainha Campos A, et al.: Deep Brain Stimulation for Refractory Cocaine Dependence. Biol Psychiatry. 2016; 79(11): e87-9.

PubMed Abstract | Publisher Full Text | F1000 Recommendation

53. F Corripio I, Sarró S, McKenna PJ, et al.: Clinical Improvement in a TreatmentResistant Patient With Schizophrenia Treated With Deep Brain Stimulation. Biol Psychiatry. 2016; 80(8): e69-70.

PubMed Abstract | Publisher Full Text | F1000 Recommendation

54. F Lipsman N, Lam E, Volpini M, et al:: Deep brain stimulation of the subcallosal cingulate for treatment-refractory anorexia nervosa: 1 year followup of an open-label trial. Lancet Psychiatry. 2017; 4(4): 285-94. PubMed Abstract | Publisher Full Text | F1000 Recommendation

55. F Lipsman N, Woodside DB, Giacobbe $\mathrm{P}$, et al:: Subcallosal cingulate deep brain stimulation for treatment-refractory anorexia nervosa: a phase 1 pilo trial. Lancet. 2013; 381(9875): 1361-70.

PubMed Abstract | Publisher Full Text | F1000 Recommendation

56. Nuttin $\mathrm{B}, \mathrm{Wu} \mathrm{H}$, Mayberg $\mathrm{H}$, et al.: Consensus on guidelines for stereotactic neurosurgery for psychiatric disorders. J Neurol Neurosurg Psychiatry. 2014 85(9): 1003-8.

PubMed Abstract | Publisher Full Text | Free Full Text

57. Schrock LE, Mink JW, Woods DW, et al.: Tourette syndrome deep brain stimulation: a review and updated recommendations. Mov Disord. 2015; 30(4): 448-71.

PubMed Abstract | Publisher Full Text

58. F Beeker T, Schlaepfer TE, Coenen VA: Autonomy in Depressive Patients Undergoing DBS-Treatment: Informed Consent, Freedom of Will and DBS' Potential to Restore It. Front Integr Neurosci. 2017; 11: 11. PubMed Abstract | Publisher Full Text | Free Full Text | F1000 Recommendation

59. Berridge KC, Robinson TE, Aldridge JW: Dissecting components of reward: 'liking', 'wanting', and learning. Curr Opin Pharmacol. 2009; 9(1): 65-73. PubMed Abstract | Publisher Full Text | Free Full Text 


\section{Open Peer Review}

\section{Current Peer Review Status:}

\section{Editorial Note on the Review Process}

Faculty Reviews are review articles written by the prestigious Members of Faculty Opinions. The articles are commissioned and peer reviewed before publication to ensure that the final, published version is comprehensive and accessible. The reviewers who approved the final version are listed with their names and affiliations.

\section{The reviewers who approved this article are:}

\section{Version 1}

\section{Jens Volkmann}

Department of Neurology, University Hospital of Würzburg, Würzburg, Germany Competing Interests: Jens Volkmann is a consultant to Boston Scientific and Newronika and has received honoraria for speaking on behalf of Boston Scientific, Medtronic and St. Jude, all manufacturers of deep brain stimulation systems.

\section{Tipu Z. Aziz}

${ }^{1}$ Nuffield Department of Surgery, University of Oxford, Oxford, UK

2 John Radcliffe Hospital, Oxford, UK

Competing Interests: No competing interests were disclosed.

The benefits of publishing with F1000Research:

- Your article is published within days, with no editorial bias

- You can publish traditional articles, null/negative results, case reports, data notes and more

- The peer review process is transparent and collaborative

- Your article is indexed in PubMed after passing peer review

- Dedicated customer support at every stage

For pre-submission enquiries, contact research@f1000.com 